gradient in a furnace. A uniform temperature gradiont is suitable.

A detailed account of this work has been submitted for publication elsewhere.

National Standards Laboratory,

W. A. CAW

R. G. WYLIE

Commonwealth Scientific and

Industrial Research Organization,

Sydney.

Sept. 10.

${ }^{1}$ Mardles, E. W. J., Nature, 182, 438 (1958).

\section{Temperature and Turbulence in Quiescent Prominences determined from Line-widths}

Some years ago, one of us attempted to determine the kinetic temperature of atoms and a possible turbulence in some quiescent prominences ${ }^{1}$. Since at that time the different lines of a prominence had to be exposed one after the other and since only $\mathrm{H} \beta$ and D3 could be used for the purpose, it seemed desirable to make further observations of solar prominences with improved equipment ${ }^{2}$.

The present observations were made with our tower telescope $(f=24 \mathrm{~m}$.) using a Bausch and Lomb concave grating (radius of curvature $665 \mathrm{~cm}$.). The prominences were guided on to the slit of the spectrograph (height of the slit $0.6 \mathrm{~mm}$.) by using a Lyot $\mathrm{H} \alpha$ filter ${ }^{3}$. The following lines-arising with good approximation in an optically thin layer-could be exposed simultaneously : $\lambda \mathbf{8 5 4 2}$ and (in some spectra) $\lambda 8498$ of $\mathrm{Ca}, \lambda 5875$ of $\mathrm{He}, \lambda 4340$ and $\lambda 3970$ of $\mathrm{H}$, the Balmer lines in the second order, the other lines in the first order. Since the molecular weight of calcium is forty times greater than that of hydrogen, the separation of temperature and turbulence is fairly certain. All line-widths have been corrected for the finite resolving power of the spectrograph.

Table 1 gives the results for ten quiescent prom. inences. The temperatures and the turbulent velocities are mean values computed according to the method of least squares, giving double weight to the widths of the Balmer lines. The different values given for one and the same prominence belong to different exposures. The scatter expresses, there- fore, not only the uncertainty of the measurements but also local differences in temperature and turbulence within a prominence, since it was not always possible to place the same spot of the prominence on the slit of the spectrograph for all exposures.

The kinetic temperatures-significantly higher than the excitation temperatures derived earlier ${ }^{1}$-and the turbulence in quiescent prominences are probably of the same order of magnitude as in the lower chromosphere. A slight but significant negative correlation $(r=-0 \cdot 52, n=39)$ exists between kinetic tempera. ture and turbulence. This correlation is somewhat more conspicuous if the $\mathrm{H}$ and $\mathrm{He}$ lines are treated separately $(r=-0 \cdot 64, n=35)$, and is absent if the $\mathrm{He}$ and $\mathrm{Ca}+$ lines are treated separately. From a physical point of view the negative correlation is likely to be a pseudo-correlation, suggesting that the Balmer lines arise in a different layer of a prominence from the D3 line of $\mathrm{He}$ and the $\mathrm{Ca}+$ lines.

A detailed discussion of our improved observations will appear shortly in the Nachrichten der Akademie der Wissenschaften in Göttingen, Math.-Phys.-Klasse.

P. TEN BRuggencate G. Elste

Universitäts-Sternwarte, Göttingen. Sept. 4.

${ }^{1}$ Bruggencate, P. ten, Nachr. d. Akad. d. Wissensch. Göttingen, Math.Phys.-Klasse, Nr. 13 (1952).

'See also Unsöld, A., "Physik d. Sternatmosphären", 2. Aufl., 682 (Springer, 1955).

${ }_{3}$ Bruggencate, P. ten, and Voigt, H. H., Nachr. d. Akad. d. Wissensch. Göttingen, Math.-Phys.-Klasse, Nr. 8 (1958).

\section{Electron Spin Resonance in Carbons: a New Oxygen Effect}

Ingram and Tapley ${ }^{1}$ and Uebersfeld and Erb ${ }^{2}$ have observed that electron spin resonance in certain carbons can be affected by oxygen. Austen and Ingram $^{3}$ showed that the electron spin resonance signal given by a carbon in vacuum may be $(a)$ broadened, (b) reduced in total integrated intensity, by exposure to oxygen at room temperature. In both cases, it was found possible to restore the signal to the value it possessed in vacuum by outgassing the sample for a few minutes at room temperature.

Table 1

\begin{tabular}{|c|c|c|c|c|c|}
\hline $\begin{array}{l}\text { U.T. } \\
1957\end{array}$ & $\begin{array}{c}T \text { kin } \\
\text { (deg.K.) }\end{array}$ & $\begin{array}{c}v_{\text {turb }} \\
(\mathrm{km} . / \mathrm{sec} .)\end{array}$ & $\begin{array}{l}\text { U.T. } \\
1957\end{array}$ & $\begin{array}{c}T_{\text {kin }} \\
\text { (deg.K.) }\end{array}$ & $\begin{array}{c}\text { vturb } \\
(\mathrm{km} . / \mathrm{sec} .)\end{array}$ \\
\hline $\begin{array}{l}\text { May 1 } \\
\text { 6h. } 24 \mathrm{~m} .-6 \mathrm{~h} .35 \mathrm{~m} . \\
\text { W., } 40^{\circ} \text { s. }{ }^{*}\end{array}$ & $\begin{array}{l}4,800 \\
5,000 \\
4,800\end{array}$ & $\begin{array}{l}9 \cdot 2 \\
9 \cdot 0 \\
9 \cdot 2\end{array}$ & $\begin{array}{l}\text { May } 11 \\
\text { 9h. } 45 \mathrm{~m} .-10 \mathrm{~h} .00 \mathrm{~m} \\
\text { E., } 35^{\circ} \mathrm{N} .\end{array}$ & $\begin{array}{l}7,000 \\
7,100 \\
5,200 \\
5,100\end{array}$ & $\begin{array}{l}6 \cdot 3 \\
6 \cdot 1 \\
6 \cdot 1 \\
5 \cdot 7\end{array}$ \\
\hline $\begin{array}{l}\text { May 1 } \\
\text { 7h. } 00 \mathrm{~m} .-7 \mathrm{~h} .14 \mathrm{~m} . \\
\text { E., } 30^{\circ} \mathrm{S} .\end{array}$ & $\begin{array}{l}6,500 \\
5,900\end{array}$ & $\begin{array}{l}4 \cdot 9 \\
5 \cdot 0\end{array}$ & $\begin{array}{l}\text { May } 15 \\
\text { 6h. } 35 \mathrm{~m} .-6 \mathrm{~h} .45 \mathrm{~m} . \\
\text { E., } 10^{\circ} \mathrm{N} .\end{array}$ & $\begin{array}{l}6,300 \\
7,000 \\
8,200\end{array}$ & $\begin{array}{l}3 \cdot 9 \\
3 \cdot 9 \\
3 \cdot 6\end{array}$ \\
\hline $\begin{array}{l}\text { May } 9 \\
\text { 13h. } 45 \mathrm{~m} .-14 \mathrm{~h} .00 \mathrm{~m} \\
\text { W., } 63^{\circ} \mathrm{s} .\end{array}$ & $\begin{array}{l}9,300 \\
8,600 \\
5,500 \\
5,900 \\
6,000\end{array}$ & $\begin{array}{l}4 \cdot 9 \\
5 \cdot 7 \\
6 \cdot 7 \\
7 \cdot 1 \\
6 \cdot 3\end{array}$ & $\begin{array}{l}\text { May 25 } \\
\text { 8h. } 25 \mathrm{~m} .8 \mathrm{~h} .45 \mathrm{~m} . \\
\text { W., } 10^{\circ} \mathrm{S} .\end{array}$ & $\begin{array}{l}6,300 \\
7,000 \\
6,800 \\
6,000 \\
5,500\end{array}$ & $\begin{array}{l}3 \cdot 6 \\
4 \cdot 8 \\
3 \cdot 8 \\
3 \cdot 9 \\
4 \cdot 8\end{array}$ \\
\hline $\begin{array}{l}\text { May } 9 \\
\text { 14h. } 30 \mathrm{~m} .-14 \mathrm{~h} . \\
\text { E., } 33^{\circ} \mathrm{N} .\end{array}$ & $\begin{array}{l}5,800 \\
5,200 \\
4,600 \\
4,500\end{array}$ & $\begin{array}{l}7 \cdot 6 \\
7 \cdot 5 \\
7 \cdot 6 \\
8 \cdot 6\end{array}$ & $\begin{array}{l}\text { Junc } 13 \\
\text { 6h. } 12 \mathrm{~m} .-6 \mathrm{~h} .21 \mathrm{~m} . \\
\text { E., } 40^{\circ} \text { N. }\end{array}$ & $\begin{array}{l}7,600 \\
7,900 \\
7,300 \\
6,500\end{array}$ & $\begin{array}{l}5 \cdot 6 \\
4 \cdot 9 \\
4 \cdot 9 \\
5 \cdot 0\end{array}$ \\
\hline $\begin{array}{l}\text { May } 10 \\
\text { 8h. } 10 \mathrm{~m} .-8 \mathrm{~h} .15 \mathrm{~m} . \\
\text { E., } 33^{\circ} \mathrm{N} .\end{array}$ & $\begin{array}{l}7,500 \\
6,900 \\
6,300 \\
4,500\end{array}$ & $\begin{array}{l}6 \cdot 5 \\
6 \cdot 7 \\
6 \cdot 1 \\
6 \cdot 4\end{array}$ & $\begin{array}{c}\text { June } 13 \\
\text { 16h. } 04 \mathrm{~m} .-16 \mathrm{~h} .30 \mathrm{~m} . \\
\text { W., } 0^{\circ}\end{array}$ & $\begin{array}{l}8,800 \\
5,900 \\
5,000 \\
7,700 \\
6,600\end{array}$ & $\begin{array}{l}6 \cdot 6 \\
7 \cdot 3 \\
7 \cdot 3 \\
6 \cdot 1 \\
7 \cdot 0\end{array}$ \\
\hline
\end{tabular}

* Position of prominences according to "Daily Maps of the Sun", Fraunhofer Institut, Freiburg im Breisgau. 